\section{SOCIAL WORK WITH OLDER ADULTS IN THE UNITED STATES}

\author{
Andrew E. Scharlach \\ UCB \\ Scharlach@berkeley.edu
}

Citation/Cómo citar este artículo: Scharlach, A. E. (2015). "Social Work with Older Adults in the United States". Arbor, 191 (771): a207. doi: http://dx.doi.org/10.3989/ arbor.2015.771n1009

Received: January 16, 2014. Accepted: July 25, 2014.

\section{TRABAJO SOCIAL CON LOS MAYORES EN LOS ESTADOS UNIDOS}

Copyright: @ 2015 CSIC. This is an open-access article distributed under the terms of the Creative Commons Attribution-Non Commercial (by-nc) Spain 3.0 License.
ABSTRACT: This article examines ageing services in the United States, which are provided and financed through a mixed economy of care that includes government, the voluntary sector, and the private market. Because of substantial unmet needs, poorly coordinated systems, and social and economic disparities among older adults in the United States, social-work services have an important role to play in overcoming barriers to optimal functioning and emotional well-being in later life. Existing evidence suggests that the ability of social work to meet the needs of a growing ageing population is hampered by insufficient numbers of social workers with adequate training and competence in ageing. The article analyses and discusses recent advances in social work education in the United States designed to produce greater numbers of ageing-competent social work professionals, including initiatives in aging-related curriculum development, training, organisational development, and scholarship.

KEYWORDS: Social Work; care coordination; ageing services; ageing policy; Social Work education; United States.
RESUMEN: Este artículo examina los servicios de asistencia a los mayores en los Estados Unidos. Estos servicios se prestan y se financian por medio de un sistema de atención que incluye al gobierno, al sector del voluntariado y al mercado privado. A causa de las necesidades básicas no satisfechas, de los sistemas mal coordinados y de las disparidades sociales y económicas entre los adultos mayores en los Estados Unidos, los servicios de asistencia social desempeñan un papel importante en la superación de las dificultades para alcanzar el funcionamiento óptimo y el bienestar emocional en la edad avanzada. La insuficiencia de trabajadores sociales con una adecuada formación y competentes en envejecimiento reduce la capacidad del Trabajo Social para satisfacer las necesidades de un número creciente de población mayor. El artículo analiza y discute los avances recientes en la formación de los trabajadores sociales en los Estados Unidos, avances que tienden a aumentar el número de trabajadores sociales competentes en envejecimiento e incluyen iniciativas para el desarrollo del curriculum relativo al envejecimiento, la capacitación, el desarrollo organizativo y la escolarización.

PALABRAS CLAVE: Trabajo Social; coordinación de la atención; los servicios de asistencia a los mayores; la política de asistencia gerontológica; la formación en Trabajo Social; Estados Unidos. 


\section{AN AGEING WORLD}

The world is growing older. In 2006, almost 500 million people worldwide were age 65 or older, representing about $8 \%$ of the global population. By 2030 , that total is projected to increase to at least one billion people, $13 \%$ of the earth's inhabitants. For the first time in the history of humankind, the elderly will outnumber children. In the middle of the $20^{\text {th }}$ century, there were nearly three times as many children under the age of five as there were persons age 65 or older; by the middle of the $21^{\text {st }}$ century, this situation will have nearly reversed (United Nations, 2005).

The aging of the population reflects a number of interrelated trends. On the one hand, more people simply are living long enough to be old, largely as a result of improved health practices, sanitation, and dramatic reductions in communicable diseases. At the same time, life expectancy has been increasing among the elderly as well, and there remains substantial disagreement regarding whether there is a natural limit to the human lifespan. As a result, the number of very old individuals is rising rapidly, and the population 85 and older represents the fastest growing age group in many societies. Population aging also is a result of unprecedented declines in the number of children being born throughout the world. In developed countries, fertility rates have declined to below replacement rates (approximately 2.1 births per woman), resulting in net reductions in the total populations of some countries.

While population aging is a major achievement, it also is likely to be accompanied by some significant challenges. As people live longer and have fewer children, family structures are being transformed from the traditional pyramid to more of a beanpole, with four, five, or even six generations alive at the same time. With more elderly family members and fewer younger members, the capacity of families to provide assistance to their elderly members will be challenged.

Work patterns also are changing, with individuals spending a much greater proportion of their lives in the post-employment phase. While Europe currently has four people of working age for every older citizen, it will have only two workers per older citizen by 2050 as a result of the baby boom generation retiring and life expectancy increasing. Increasing life expectancies, coupled with a smaller percentage of workers, are already beginning to strain health and pension systems, leading many countries to reevaluate the sustainability of existing social insurance systems (Dobriansky, Suzman and Hodes, 2007).

Despite these challenges, population aging also affords numerous opportunities. Indeed, population aging has been called "one of the crowning achievement of the last century" (Dobriansky, Suzman and Hodes, 2007, p. 1). As the G8 Labour Ministers concluded when they met in 2000 to consider the economic implications of an aging population: "the ageing of our societies will create new opportunities as well as challenges; there is nothing inevitable about the impact of ageing on society; older people represent a great reservoir of resources for our economies and societies" (G8 Information Centre, 2000).

\section{AGING IN THE UNITED STATES}

Demographic changes. Between now and 2050, the percentage of the United States (U.S.) population age 65 and older is projected to increase from $13 \%$ to $20 \%$, resulting in an elderly population of almost 89 million individuals by the middle of the century (U.S. Census Bureau, 2010). This population growth is due to three interrelated factors: (1) the aging of the Baby Boom population, the nearly 80 million Americans born between 1946 and 1964 (Frey, 2007); (2) increased longevity, as individuals who survive to age 65 today can expect to live well into their 80s (Federal Interagency Forum on Aging-Related Statistics, 2008); and, (3) decreased fertility rates, which have fallen from 3.7 in the 1960 s to 1.9 currently. As a result, the U.S. population age 65 and over is projected to increase by $120 \%$ between 2005 and 2050, whereas the rest of the population will increase only about $37 \%$ during this same period (Passel and Cohn, 2008).

This growth in the elderly population is likely to be accompanied by an increase in service needs. First, the greatest demographic growth is among the oldest age groups, who tend to have the greatest health and economic vulnerability. The population 85 and older is expected to more than triple over the next forty years, jumping to 19 million Americans by 2050 (U.S. Census Bureau, 2010). Rates of functional and cognitive impairment increase with age, with the overall rate of nursing home admission increasing from $39 \%$ for those age 65 to 74 to $49 \%$ for those age 85 and over (Seperson, 2002). Second, poverty rates also increase with age, so that nearly half of individuals age 85 and over are either poor or near poor. Third, Baby Boomers are in worse health than the current cohort of older adults, reporting more chronic illness, pain, physical limitations, and alco- 
hol and mental health problems than the previous generation (Soldo et al., 2006).

Diversity. American society is highly diverse racially and ethnically, and the older population is becoming more so. Currently, non-White and Latino elders represent less than $20 \%$ of the population age 65 and older: about $8 \%$ are African American, 5.6\% Latino, 2.4\% Asian and Pacific Islander, and less than $1 \%$ Native American. However, this pattern is changing rapidly. By 2030, non-White and Latino elders will form over $33 \%$ of the older population, with the most rapid growth of elders among Asian Americans, Pacific Islanders, and Latinos (U.S. Administration on Aging, 2012).

Women remain the majority of adults age 65 and older, especially among those 85 and older, a trend that will most likely continue. However, sexual orientation patterns are shifting: the number of gay/lesbian/bisexual or transgender elders is currently estimated to be 1 to 3 million, and this will grow to 2 to 6 million by 2030 .

Demographic and social characteristics translate into economic inequities and health disparities, with significantly higher poverty rates experienced by women and elders of color. For example, twice as many women age 65 and over are poor compared to their male counterparts. Nearly three times as many elderly African Americans and over twice as many Latino elders are poor compared to their Caucasian peers, with African American women age 85 and older forming the poorest group in our society (Hudson, 2002).

Health and social service access. A variety of complex changes in later life can make it difficult for older adults to meet their physical, psychological, and social needs. Age-related changes in health or physical status may be accompanied by physical disability, diminished cognitive abilities, depression or other mental illnesses, loss of social relationships, and financial hardships. Over 80 percent of adults 65 and older have at least one chronic health condition, such as heart disease, diabetes, cancer, or arthritis, and onehalf have two or more conditions. According to the National Institute of Mental Health, between one and five percent of older adults living in their own homes suffer with major depression, as do 13.5 percent of those who require home health care and 11.5 percent of older hospitalized patients. An estimated 5 million adults over age 65 have symptoms of depression that put them at risk for developing major depression.
Yet, the U.S. aging services system, including inhome services (e.g., home health care), community services (e.g., senior centers, adult day health care), institutional care (e.g., nursing homes), and material supports (e.g., wheelchairs and other assistive devices), is ill-prepared for the rapidly growing number and diversity of older adults experiencing health problems, psychosocial challenges, and disabling conditions (Ikegami and Campbell, 2002). Existing community-based support services for older adults remain highly fragmented and poorly coordinated, with gaps in service delivery, financing, and information availability (Kane, 2012).

As a result, older adults in the U.S. experience markedly high levels of unmet needs for health care and social services (Shea et al., 2003), with unmet needs highly associated with economic status, race, ethnicity, and gender. Whereas $22 \%$ of low-income elders report that their health needs go unmet, only $2.5 \%$ of middle- and upper-income elders report unmet needs (Whitfield and Hayward, 2003). Unmet needs for assistance are associated with being female, Latino, and born outside the U.S. Among families caring for disabled elderly relatives, unmet needs are 3.7 times more likely among Latinos than among Whites, in part because Latino caregivers are 1.5 times less likely than White caregivers to use formal services (Scharlach et al., 2008).

A variety of factors contribute to disparities in service access, including the following: lack of affordability; lack of availability near where elders live; inadequate transportation supports; lack of bilingual or bicultural service providers; and, inadequate support for family and community networks. In addition, immigrant elders may be reluctant to use formal services, whether because of expectations regarding family responsibility, or a mistrust of formal service providers based on a history of discrimination and exclusion (Scharlach et al., 2006).

\section{U.S. AGING POLICY CONTEXT}

Sociocultural context. Sociocultural values and norms, and associated political structures, impact the way in which aging-related social policies are developed and enacted, the types and availability of aging services, and their financing and administration. American sociocultural values emphasize individual autonomy and individual responsibility, as embodied in the country's "Declaration of Independence". A central component of this emphasis is the notion of privacy, including control of, and responsibility for, 
one's personal affairs. Individuals and their families typically are given full responsibility for providing, managing, and paying for aging services, personally and through the free market, as long as they have the human and economic resources to do so. One of the federal government's primary long-term care initiatives under both liberal and conservative administrations, for example, has been a campaign exhorting individuals to purchase private long-term care insurance rather than depend upon the government. More than two-thirds of older adults, however, have virtually no protection against costs associated with long-term care, resulting in individual vulnerability and often impoverishment.

Aging services in the US are provided and financed through a mixed economy of care, involving government programs, economic markets, and civil society, including individuals, families, and volunteer organizations. Moreover, U.S. aging policies appear to be moving towards a more balanced mix of these three major components. Indeed, increasing reliance on a mixed economy of care appears to be a global phenomenon, at least among highly developed countries, as a result of worldwide economic, demographic, social, and political pressures (Burau, Theobald and Blank, 2007).

Government role in aging services. The United States public aging services system is based primarily on a residual or "safety-net" model, whereby the government typically serves as the payor and provider of last resort, becoming involved only "when it would be socially unconscionable not to do so" (Knickman and Snell, 2002). Benefits are highly dependent on a person's economic situation, especially with regard to individual income and assets, resulting in essentially two funding and delivery systems for aging services: older adults with minimal economic resources receive heavily-subsidized services administered by public agencies and their contractors, whereas other older adults are mostly responsible for their own care. Only after impoverishment does substantial public support become available, primarily through the Medicaid program, which covers health care and long-term care (LTC) costs for individuals with low incomes and minimal assets, accounting for $49 \%$ of all LTC expenditures in 2005 (Komisar and Thompson, 2007). Because nursing home care is a mandatory entitlement under Medicaid, the vast majority of Medicaid LTC spending is for institutional care $(\$ 47$ billion for $\mathrm{NH}$ care vs. $\$ 17$ billion for home and community-based care in 2007) (AARP PPI, 2009). Medicare, the public health insurance program for older adults, covers a limited amount of temporary post-acute $\mathrm{NH}$ and home health care expenses.

Public LTC policies and programs also vary greatly from state to state, and even from town to town within the same state, reflecting the federalist history of states' rights in the U.S. For example, per capita Medicaid LTC expenditures range from $\$ 65 /$ year in Utah to \$491/year in New York. Moreover, while some states (e.g., Indiana, North Dakota) spend at least $95 \%$ of their Medicaid LTC dollars on nursing home care, other states (e.g., Alaska, California, New Mexico) devote the majority of their Medicaid LTC expenditures to home and community-based services (AARP,PPI, 2009). Some urban areas offer a rich array of supports for older adults and persons with disabilities, while many rural areas lack any formal service delivery structures.

The increasing numbers of elderly persons with chronic disabling conditions, decreased availability of family care, and concern about the high public costs of long-term care have prompted a number of government policy initiatives designed to reduce government responsibility for LTC by promoting increased individual and family responsibility, and by "rebalancing" public LTC expenditures to increase home and community-based care and reduce $\mathrm{NH}$ utilization (Scharlach and Lehning, 2012; U.S. Administration on Aging, 2012; Vincent and Velkoff, 2010). A primary focus has been on incentives for enhancing the effectiveness and efficiency of community-based aging services while reducing access to $\mathrm{NH}$ care. The "Money Follows the Person" demonstration project, for example, provided $\$ 1.75$ billion in federal funding to assist poor disabled individuals to move from institutional to community settings (Shirk, 2006). Other Medicaid waiver programs (e.g., the Program for AllInclusive Care for the Elderly [PACE]) allow states to use federal and state dollars to pay for communitybased LTC services for individuals who might be cared for in an institutional setting.

In March of 2010, the U.S. passed the Patient Protection and Affordable Care Act (H.R. 3590), which included a number of provisions explicitly designed to promote community care, including the Independence at Home Demonstration Program, Community First Choice Option, Money Follows the Person Rebalancing Demonstration, and Community-Based Care Transitions Program. The major LTC component of the Patient Protection and Affordable Care Act was a Community Living Assistance Services and Supports Act 
(CLASS Act), the first comprehensive effort by the U.S. government to assist middle-class individuals with LTC costs. This voluntary insurance program, which was to be funded by payroll deductions and direct contributions, would have provided a cash benefit to offset some of the cost of LTC services, such as home health care, adult day health care and institutional care in an ALF or NH (Kaiser Family Foundation, 2010). However, largely because of political resistance to expanded government programs, as well as concerns that the voluntary nature of the program would lead to adverse selection, undermining the financial stability of the program, the CLASS Act was repealed as part of a federal budget agreement in 2013.

The role of the market. American economic and political traditions invest the private sector with primary responsibility for providing the goods and services needed by individual consumers. While the marketplace for LTC has been somewhat slow to develop on the scale needed to respond to the growing number of older disabled persons, the U.S. has more than 15,000 privately-run nursing homes and other residential care facilities (American Health Care Association, 2013), and more than 5,000 privately-run Medicarecertified home care agencies (National Association for Home Care and Hospice [NAHCH], 2008). By comparison, non-profit organizations operate about 6,000 nursing homes and other residential care facilities and programs (Leading Age, 2013), and about 1,000 Medicare-certified home care agencies (NAHCH, 2008).

Out-of-pocket spending by consumers and their families was responsible for about $18 \%$ of nursing home and home health care expenditures in 2005 (Komisar and Thompson, 2007); however, these numbers do not include the majority of home care services provided by local companies and independent providers, suggesting that actual total out-of-pocket spending for LTC probably is many times that number. In the U.S., there also is a substantial gray market in elder care, consisting primarily of immigrants who provide home care at a lower cost than private companies.

The federal government has tried to promote the purchase of private long-term care insurance (LTCI) by making premiums and benefits tax-deductible for policies that meet certain basic standards, in an effort to reduce impoverishment and thus require government assistance with LTC. However, LTCl plays a relatively small role in the overall LTC picture; LTCI and health insurance combined accounted for only about 7\% of LTC spending in 2005 (Komisar and Thompson, 2007). Moreover, some have argued that LTC presents a classic example of market failure, given the difficulty of estimating the risks involved, the limited options available, and the constraints on consumers' ability to locate and take advantage of the most desirable and cost-effective alternative source of care.

The role of civil society. The U.S. has a lengthy tradition of voluntary organizations and supports (e.g., religious institutions, non-governmental communal agencies), and these play a major role in LTC provision. Family members, friends, and other members of elders' social networks provide the vast majority of LTC assistance. Of elders who receive in-home care, about two-thirds receive care only from informal sources and another $30 \%$ receive assistance from a combination of formal and informal sources (U.S. Department of Housing and Human Services, 1998). Unpaid care from family members and other informal sources is valued at more than $\$ 375$ billion a year (Houser and Gibson, 2008), making informal care the largest source of long-term care. This reflects the dominant political view that families should have the primary care responsibility for dependent members. Government efforts to support and incentivize family LTC provision have included the Family and Medical Leave Act in 1993 and the National Family Caregiver Support Program in 2000. More recently, the Cash \& Counseling demonstration model (under Medicaid's 1915(j) waiver program) has provided consumers in some states with a monthly allowance, which they can use for virtually any care-related expenses, including hiring family members. Moreover, while not currently enforced, 30 of the 50 states have family responsibility laws that mandate family support for disabled older persons before those individuals can qualify for public benefits.

Variations and disparities. Support services for older adults in need of assistance in the US tend to vary greatly, depending upon individuals' economic resources, as well as state and local policies, program and service availability, and culture-based norms regarding family responsibility. Economic resources are a prime determinant of the type and location of services, who provides the services, and how they are paid for.

Older adults with substantial income and assets, for example, typically have the ability to use personal funds or private LTC insurance to purchase home care and other needed services from the private, for-profit market. Home care most often is provided by a private company or an independent provider, frequently by immigrants working in the gray market. Older 
adults with sufficient personal funds also can pay for care in an ALF, typically entering a private $\mathrm{NH}$ only if care coordination and supervision break down (e.g., due to cognitive impairment or the lack of an available family member).

Older adults with moderate income and assets typically receive minimal public support with needed services. They are more likely to rely on family members to provide care, turning to independent providers and private for-profit or not-for-profit companies to supplement family care as needed. The ability to move to an ALF would depend upon having sufficient resources, as well as the local cost of ALF care. When the family was no longer able to provide care or the older adult could no longer afford the cost of paid care, a move to a $\mathrm{NH}$ might be necessary. $\mathrm{NH}$ care would be paid entirely from personal funds until those funds were exhausted, at which time $\mathrm{NH}$ care would be covered by a combination of public and voluntary funds. It is estimated that nearly three-fourths of older adults would become totally impoverished if they had to pay for costs associated with a two or three year stay in a nursing home (Knickman and Snell, 2008).

Older adults who are very poor (i.e., with assets totaling less than $\$ 2,000$ in most states) typically are eligible to receive home care (up to a predetermined maximum number of hours) paid for by public (federal and state) funds. Public funds could be used to pay for care by a family member (in some states), by an independent provider, or by a voluntary-sector home care company. Moving to an ALF, which are mostly market rate and not covered by public funds, would be unlikely. When care needs exceeded what could be provided at home, the older adult most likely would move to a $\mathrm{NH}$, where care would be fully covered by public dollars, although recent federal and state policy initiatives are striving to reduce access to $\mathrm{NH}$ care for low-income elders.

\section{ROLE OF SOCIAL WORK IN AGING SERVICES}

Social work has a particular focus on helping vulnerable individuals to obtain needed services and supports. Social workers are unique among health care providers because they are trained to address and manage the complexities of each client's situation, taking into account how physical, psychological, and socioeconomic factors interact in ways that can impact all aspects of a person's life and health. Social work interventions with older adults are directed at enhancing dignity, self-determination, personal fulfillment, a decent standard of living, optimum func- tioning, and the least restrictive living environment possible. In addition, the distinctive value social work places on the uniqueness of individuals within a systems perspective prepares social workers to play a key role in designing and implementing equitable and effective programs and policies to meet the needs of increasingly diverse older populations.

The California Social Work Education Center (California Social Work Education Center [CalSWEC], 2006) has identified eight basic principles of social work practice with older adults:

1. The goal of services for older people is to maintain independence; optimize physical, psychological, and social functioning; and maximize the quality of life.

2. Services for older persons should be guided by the individual's goals, strengths, needs, and concerns, with appreciation for the interconnectedness among physical, psychological, and social aspects of well-being.

3. Family relationships should be respected and fostered, with the goal of strengthening reciprocal bonds, enabling family care over time, and preventing undue hardship.

4. The growing diversity of the older population in ethnicity, language, culture, and immigration status must be reflected in culturally competent staff and program design.

5. Racism, sexism, and other forms of discrimination influence the opportunities of individuals over the life course and systems of care for older people must address the needs of those who have been marginalized or disadvantaged during their lives.

6. Older persons have the right to live in their homes and communities as long as possible supported by community services.

7. Older persons whose cognitive capacity is diminished should be provided with legally mandated, humane, and protective services from family or public systems.

8. Services across a full continuum should be available, accessible, coordinated, timely, and effective.

Social work has a particular emphasis on serving vulnerable individuals and groups, including older adults who have chronic physical or cognitive limitations, limited financial resources, or are socially 
isolated. By helping older adults to overcome barriers such as these, social workers can help to maximize physical and psychological well-being, preserve independence, and potentially reduce unnecessary economic and social costs to individuals, families, and service systems.

While the evidence base for social work with older adults is somewhat limited, it seems likely that social work services can help to ameliorate the physical, psychosocial, familial, organizational, and societal factors which serve as barriers to optimal functioning and emotional well-being in later life. A review of evidence regarding the effectiveness of social work services in aging (Rizzo and Rowe, 2006), for example, found that social work can improve coordination of health care services, increase service satisfaction, reduce caregiver strain, shorten lengths of inpatient hospitalization, and decrease inappropriate use of emergency rooms.

Care Coordination. A central mechanism by which social work services benefit older adults is through identifying and coordinating services and supports that respond to each individual's unique situation and needs. Care coordination has been associated with a number of salutary outcomes, including reduced mortality, improved social and emotional well-being, improved quality of life, reduced or delayed nursing home admissions, and decreased caregiver burden (e.g., Bernabei et al., 1998; Boult et al., 2009; Challis et al., 2002; Counsell et al., 2007; Onder et al., 2009). Recipients of case management and care coordination services receive better quality care, are more satisfied with the services they receive, and are more apt to adopt preventive strategies than are persons who receive traditional care without care coordination (Boult et al., 2009; Onder et al., 2009).

Care coordination can be a key to enhancing the quality and effectiveness of community support service systems (Challis et al., 2002). Potential system impacts include lower health care costs (e.g., Beland et al., 2006; Bernabei et al., 1998; Boult et al., 2009), typically through reductions in hospital admissions and shorter stays (e.g., Bernabei et al., 1998; Shier et al., 2013). Findings from Medicare's Demonstration Projects on Disease Management, Care Coordination, and Value-Base Payment suggest that increased incentives for care coordination in Medicare payment and delivery systems have the potential to reduce costs and improve quality (CBO, 2012). However, not all studies have produced such favorable results. Some randomized controlled trials, for example, have found that intensive case management was no better than simple information and referral in its effect on medical costs and patient well-being (Boult et al., 2000; Enguidanos and Jamison, 2006; Tourigny et al., 2004).

Social workers have particular strengths as providers of care coordination. The bulk of evidence suggests that the primary mechanism by which care coordination produces positive outcomes is by helping vulnerable persons to obtain needed resources and services, and overcoming barriers associated with personal or social limitations or structural barriers that affect service availability or accessibility (Challis et al., 2002; Freij et al., 2011). Analyses of care coordination models suggest the particular importance of three services typically provided by social workers: comprehensive initial screening and assessment; client involvement and advocacy; and, family education and support (Hyduk, 2002; Kelsey and Laditka, 2009). Some studies have found particular benefits, such as reduced hospitalizations, associated with care coordination by social workers but not by nurses (e.g., Enguidanos et al., 2011).

A multi-year analysis of care coordination in the UK found that assessments and care plans created by social workers were more comprehensive than those developed by other personnel, and users received care that was more reliable and more effective at meeting their needs (Challis et al., 2002). Individuals receiving care coordination from social workers, compared with matched controls, had dramatically lower institutionalization rates, greater psychological well-being (e.g., higher morale, life satisfaction, and coping ability; lower depression, less loneliness), greater social activity (e.g., more social interactions, more out-of-home activity), reduced unmet needs for personal care and household care, and improved caregiver well-being (e.g., decreased strain and psychological stress; improved social life), with no difference in costs for social services, health care, or housing (Challis et al., 2002).

Social work can be particularly effective as an adjunct to traditional medical care. Social work support services (e.g., care coordination, patient education, and family support services) with stroke patients result in better medical adherence and reduced hospital costs (Rizzo and Rowe, 2006). In one study, elderly veterans whose spouses participated in support groups led by social workers had annual health care costs $\$ 7,500$ lower than those whose spouses received usual care (Peak, Toseland and Banks, 1995). Problem-solving therapy from social workers housed in primary care offices has been found to improve patients' ability to identify problems they would like to 
solve while providing the assistance to help them do so. The types of health and health-related problems most often identified, including information about their medical condition, medical equipment needs, health behaviors such as exercise and weight loss, and home and garden maintenance, were twice as likely to be solved as those identified by health care professionals (Enguidanos et al., 2011). An analysis of services received by private long-term care insurance beneficiaries found that care coordination, typically by social workers, improved care access and enhanced quality assurance (Scharlach et al., 2003).

While best practices of care coordination are still in development, some emerging findings are pointing to service components that may have particular utility. A recent study of a care coordination program that combined comprehensive personal and environmental assessment, multi-level care coordination, a mix of professional and volunteer providers, referral to a vetted network of preferred providers, and a single access point, for example, found evidence of increased client mobility and social activity, reduced social isolation, improved ability to meet household needs, greater access to health care, reduced falls, reduced use of hospital emergency room and inpatient services, and greater perceived ability to age in place (Scharlach, Graham and Berridge, 2012).

Aging-Friendly Community Initiatives. Social workers have an important role to play not only in services designed to ameliorate problems experienced by older adults and their families, but also in preventive efforts designed to change the context within which aging occurs, by helping communities to become more "aging-friendly." An aging-friendly community is one in which older adults continue to engage in lifelong interests and activities, retain a sense of control over their lives, maintain fulfilling social and emotional connections, contribute in meaningful ways to the well-being of other persons and the community at large, enjoy opportunities to develop new interests and sources of fulfillment, and receive necessary supports and accommodations to help them accomplish those tasks and meet their basic needs (Scharlach, 2009).

In recent years a growing number of governments, nonprofit organizations, and foundations have implemented initiatives designed to create more "agingfriendly" communities, characterized by a comprehensive view of the needs of older adults (Hodge, 2008). These initiatives include efforts by the World Health Organization, U. S. Administration on Aging,
Robert Wood Johnson Foundation, AARP, National Association of Area Agencies on Aging and Partners for Livable Communities, Visiting Nurse Service of New York, among others.

A 2009 survey of community aging initiatives in the US identified five types of community change initiatives: 1) single sector services, 2) communitywide planning, 3) cross-sector systems change, 4) residence-based support services, and 5) consumerdriven support networks (Lehning, Scharlach and Wolf, 2012). Single sector service initiatives primarily involve new, expanded, or improved access for specific types of services such as housing or transportation, but are not working towards overall system change. Community-wide planning efforts, such as the World Health Organization's Global Age-Friendly Cities Program, typically include government-initiated community-wide needs assessment and strategic planning efforts, employing social work methods such as individual and community assessment, intervention planning, and community education. Crosssector systems change initiatives, such as the Robert Wood Johnson Foundation's Community Partnerships for Older Adults (CPFOA), involve inter-organizational collaborations across existing service delivery sectors in order to enhance existing programs and services for older adults. Residence-based support services, such as the NORC Supportive Services Program, typically involve collaborations between geographically-defined housing settings and local service providers.

Finally, consumer-driven support networks, such as the "Village" model, engage older community residents in consumer-driven associations that provide peer support and social activities. In return for annual dues, Village members receive a variety of services and support, including access to core services (e.g., weekly grocery shopping trips), referrals and discounts to vetted outside services (e.g., home repair), social and educational activities, and opportunities to participate in meaningful and fulfilling volunteer roles. Consumer engagement is a key feature of these organizations, including developing the initiative, providing oversight and governance, and offering support and services to other members. To date, more than 100 consumer-driven senior membership associations have emerged across the United States. Approximately $30 \%$ of these organizations have staff members with MSW degrees. Among the social work skills required to operate a Village are the following: community organizing, re- 
source brokerage, advocacy, group facilitation, consumer education, training, volunteer development, and management and administration (McDonough and Davitt, 2011).

Social workers have a unique combination of the knowledge and skills that are critical to the development of age-friendly communities (Barusch, 2013). Trained in an ecological perspective that focuses on improving the fit between individuals and their environments, social workers are accustomed to working on problems that cross traditional disciplinary boundaries and address a variety of interconnected issues, affecting the health and well-being of individuals, families, organizations, and communities. Social workers are particularly sensitive to the needs of vulnerable populations, and are committed to the empowerment and self-determination of individuals as well as the communities in which they live. Initiatives to promote aging-friendly community change inherently involve interventions at these multiple levels, including the following: individual capacity building (e.g., enhanced competence, physical and psychosocial functioning, coping strategies, and empowerment); social networks (e.g., social engagement, social support, social capital development); person-environment fit (e.g., social inclusion, aging-in-place); organizational and system capacity-building (e.g., service availability, accessibility, affordability, and appropriateness); community development (e.g., social capital development, local planning); and, societal change (e.g., social and economic policies, culture change) (Scharlach, 2009).

Individual and communal involvement in change processes, a core component of social work empowerment efforts, can be especially beneficial to older adults and their communities. Community involvement has been found to enhance self-efficacy (i.e., an individual's belief in his or her ability to achieve goals and make desired changes) (Bandura, 1982), personal feelings of empowerment (Corrigan, 2006; Itzhaky and York, 2000a; Itzhaky and York, 2000b; Zimmerman and Rappaport, 1988), and collective efficacy (i.e., community members' shared beliefs that they can bring about desired community change) (Price and Behrens, 2003; Sampson and Raudenbush, 1999). Consumer involvement can also help organizations and communities to improve service quality and be more responsive to local needs (Parker and Betz, 2000).

Combining many of these components, the University of Calgary Faculty of Social Work developed and implemented the Calgary Elder-Friendly Communi- ties Project (CEFCP), a model of community engagement and aging in place capacity building in diverse urban neighborhoods. CEFCP was a participatory, neighborhood-based, community development and research project designed to enhance capacity, foster meaningful participation, and promote aging in place for seniors and their caregivers in Calgary, Alberta. Developed in collaboration with the Calgary Regional Health Authority, the City of Calgary, Calgary Family Services, Jewish Family Services, and the Calgary Catholic Immigration Society, the project targeted four neighborhoods that were home to high percentages of seniors and differed with regard to economic status and culture.

Building upon social work faculty expertise in community change processes and engaging social work students in community needs assessment, planning, and organizing activities, the project engaged community members of diverse ages and ethnicities in community development projects such as intergenerational programs and infrastructure improvements (Austin et al., 2005). With support from community development workers, elderly community residents assumed leadership roles in community change efforts, including assessment, planning, provision, and evaluation of services (Austin et al., 2005). All programming decisions were made by senior-led groups, which were also responsible for community organizing activities such as workshops on accessing resources, local conferences, social activities, and environmental improvements. The project demonstrated the potential of social work faculty and students to engage in community capacity building and participatory research in underserved communities.

\section{WORKFORCE NEEDS}

The ability of social work to meet the needs of a growing aging population is hampered by the lack of social workers with adequate training and competence for meeting the needs of older persons and their families. The majority of licensed social workers, between $60 \%$ and $75 \%$, work in some capacity with older adults and their families, yet most of these report not having sufficient knowledge about aging ( $\mathrm{Na}$ tional Association of Social Workers [NASW], 2005). A 2004 Bureau of Labor Statistics report estimated that $60,000-70,000$ geriatric social workers would be required to meet the needs of an aging population (U.S. Department of Health and Human Services, 2006). However, in 2005 , only $9 \%$ of licensed members of 
the NASW, or fewer than 15,000 social workers, identified gerontology as their primary area of practice (Hooyman, 2006).

A 2008 study by the California Social Work Education Center (CalSWEC) found that the majority of county programs providing adult protective services (APS) for the most vulnerable elderly and disabled adults in California had no workers with any formal training in aging, as did only $30 \%$ of programs providing in-home support services (IHSS). The primary barriers identified were a lack of qualified applicants, especially applicants with experience in serving non-White and Latino elders (Moon et al., 2008).

The failure of social work educational institutions to produce an adequate number of aging-prepared social workers is a major limitation. Fewer than $5 \%$ of social work graduate students specialize in aging (Scharlach et al., 2000), and only $20 \%$ of MSW students have taken even one course on aging (Cummings, Alder and DeCoster, 2005). To some degree, this is because of students' lack of positive relationships with older adults in their personal or professional lives, and associated student concerns about their ability to help potential elderly clients (Cummings, Galambos and DeCoster, 2003; Mason and Sanders, 2004). However, availability of training opportunities also is a barrier, with fewer than $20 \%$ of MSW programs in the US offering a specialization in aging, and fewer than onethird of BSW programs even offering a single course on aging (Hooyman, 2006).

Some have suggested that lack of title protection for social work also is a problem in the US. An individual calling herself or himself a "social worker" may or may not have an advanced social work degree, often varying from state to state. It is estimated that only about half of the 750,000 individuals identifying themselves as social workers actually have social work degrees (Damron-Rodriguez, 2006). The 2008 CalSWEC study found that only $8 \%$ of county employees in social work positions actually had an advanced social work degree, even though MSW's are specified in the job descriptions for $60 \%$ of adult protective services (APS) jobs and $33 \%$ of in-home support (IHSS) jobs. These findings showed no improvement over the situation seven years earlier, when only $42 \%$ of adult protective service workers, $36 \%$ of case managers, and fewer than $10 \%$ of other county aging services personnel had advanced degrees in social work (Scharlach, Simon and Dal Santo, 2002).
Salary also is an issue, with some studies findings that social workers in aging services have the lowest average annual income of all social workers (Damron-Rodriguez, 2005). To some degree, this may be attributable to a lack of adequate reimbursement mechanisms. Public programs such as Medicare and Medicaid do not generally provide reimbursement for comprehensive assessment and care management, the core services likely to be provided by social workers.

\section{SOCIAL WORK EDUCATIONAL INITIATIVES}

Schools of social work have an important role to play in preparing the aging-competent social work professionals that are needed to serve the growing numbers of vulnerable older adults. Aging competence requires advances in curriculum development, training, organizational development, and scholarship. Important efforts already are underway in the United States, many with the support and guidance of the John A. Hartford Foundation of New York, which since 1997 has invested more than 75 million dollars in initiatives designed to enhance social work labor force capacity for meeting the needs of older adults. This investment reflects the Foundation's core mission of improving the health of older Americans by enhancing the capacity of health and allied health professionals. The Foundation's Geriatric Social Work Initiative is based largely on a framework developed by Scharlach et al. (2000), which critically examined the existing capacity of social work education for preparing a sufficient number of aging-competent social workers, and outlined major initiatives in the areas of recruitment, competency-based curriculum models, training, faculty development, and research.

Curriculum development. It is imperative that all social work students acquire the basic knowledge needed to work effectively in an aging society, including foundation-level competence in four areas: (1) human behavior and the social environment in later life; (2) practice with older adults; (3) social welfare policy regarding aging; and, (4) aging and diversity. In particular, all social work students should have a basic understanding of human development across the life-course in the context of socio-historical factors, opportunity structures, cohort differences, and adaptive resources, basic competence in the assessment of older adults, and knowledge of the policies that shape and regulate the services available to older adults. In addition, all social work students should be aware of their own attitudes regarding ageism, under- 
stand the impact of disadvantage over the life course, recognize the positive benefits of cultural values and social supports for older persons, and be able to work effectively with and on behalf of diverse groups of older persons (CalSWEC, 2006; Damron-Rodriguez, 2006). Social work programs also need to prepare aging specialists who have the knowledge and skills to assess and intervene effectively with older adults and their families, develop effective programs, and foster community and societal change. From a curriculum perspective, this requires advanced knowledge of theories of human behavior, diversity, social systems, relevant social policies, and effective programs and practice models (Damron-Rodriguez, 2006).

In order to achieve these and related goals, the $\mathrm{Na}$ tional Center for Gerontological Social Work (Gero-Ed Center) promotes curriculum development, student recruitment, educational policy development, and organizational change designed to enhance the capacity of schools of social work for developing knowledgeable and competent social workers with older adults and their families. The Gero-Ed Center's initiatives include: Curriculum Development Institutes (CDIs) to assist social work programs to infuse aging content in their curricula; a Master's Advanced Curriculum Project (MAC), that provides support for schools of social work to design advanced practice courses in substance abuse, mental health, and health-related issues with older adults; a Specialized Gerontology Program that supports schools to develop competency-based gerontology-specific curricular structures, such as a concentration, specialization, undergraduate minor, or certificate program; and, a Geriatric Enrichment in Social Work Education (GeroRich) Program to stimulate the infusion of gerontological content throughout foundation courses in social work programs. In addition, the Council on Social Work Education has published a number of collections of model syllabi for teaching social work courses on aging-related topics (e.g., Scharlach, 1999; Scharlach, 2002).

Training. The New York Academy of Medicine's Social Work Leadership Institute has developed a Practicum Partnership Program (PPP), which provides incentives and support for schools of social work and community agencies to develop and implement innovative models of aging-rich field education for social work students. The PPP, and its successor the Hartford Partnership Program for Aging Education (HPPAE), have been implemented in over 70 graduate social work education programs and have included more than 2,600 social work students (Bronstein et al., 2012). Core components include: competency-based education, expanded field instruction, rotational training models, university-community partnerships, targeted student recruitment, and leadership development. Program participants report increased competence in the areas of assessment, intervention, and service provision with elderly clients, with "advanced skill levels" increasing from $19 \%$ before participation to $68 \%$ after participation (Bronstein et al., 2012). The Consortium for Social Work Training in Aging initiated by the University of California at Berkeley, for example, created a training model that included six county department of aging services and three schools of social work, resulting in increased recruitment of students into aging programs, improved training capacity of county aging service departments, enhanced inter-organizational collaboration, and increased professional leadership in aging services (Scharlach and Robinson, 2005).

The Gero-Ed Center's BSW Experiential Learning Program provides incentives and supports for baccalaureate programs to develop structured experiential activities between undergraduate social work students and older adults. In addition, the Institute for Geriatric Social Work, housed at the Boston University School of Social Work, focuses on enhancing the gerontological competence of current social workers, through online continuing education programs, inservice training, programs, newsletters, and various other print and electronic publications on social work with older persons.

Organizational capacity development. The CSWE Gero-Ed Center provides a free consultation service designed to help social work faculty develop curriculum materials and educational experiences designed to prepare students to work effectively with older adults and their families. Gerontology curriculum experts provide consultation regarding faculty engagement, student recruitment, experiential learning, interdisciplinary education, teaching methods, specialized course development, and related areas. Consultants include social work faculty members who have successfully infused gerontological competencies and associated curriculum content in their own programs or have implemented a gerontology specialization, certificate program, or area of emphasis.

The Social Work Leadership Institute also sponsors an annual Leadership Academy in Aging, in partnership with the National Association of Deans and Directors of Schools of Social Work (NADD). The Academy provides deans and directors of social work programs with information about new developments in social 
work with older adults, while also helping them to develop new gerontology projects and initiatives at schools of social work throughout the country.

Scholarship: The Gerontological Society of America (GSA) sponsors a Faculty Scholars Program, Doctoral Fellows Program, and Doctoral Fellows Pre-Dissertation Award Program. The Faculty Scholars Program provides financial support and mentoring designed to enhance the academic development of talented junior faculty members with an interest in gerontological social work. The aim of the Faculty Scholars program is to develop future academic leaders who can teach, mentor, and conduct cutting-edge research related to the physical, psychological, and social wellbeing of older adults and their families. In so doing, the Program seeks to enhance the capacity of academic social work programs to educate and train social work practitioners to serve the growing numbers of elderly Americans. The scholars receive mentoring from nationally-recognized aging experts, and also participate in workshops designed to enhance their research and teaching skills on aging issues.

The Doctoral Fellows Program provides financial support and professional development opportunities designed to assist advanced social work doctoral students to complete their dissertations on agingrelated issues and prepare for successful academic careers in gerontological social work. The program includes academic career guidance and mentoring, professional development institutes at annual meetings of the Gerontological Society of America and the Council on Social Work Education, as well as networking opportunities with leading gerontologists, social work educators, and other doctoral students interested in aging.

The Doctoral Fellows Pre-Dissertation Award Program, now sponsored by the Association for Gerontology Education in Social Work (AGE-SW), provides doctoral students with training in research methods and academic writing, assistance developing research ideas and seeking dissertation funding, and socialization into academic gerontological social work roles. Students receive support to attend GSA's Annual Scientific Meeting, workshops on research and grant writing skills, membership in GSA and AGE-SW, and opportunities to network with Doctoral Fellows and Faculty Scholars (Bronstein et al., 2012).

AGE- SW also sponsors a newsletter, provides a professional network for social work faculty and doctoral students who have interests in aging, holds member- ship meetings at the GSA and CSWE conferences, and sponsors the Journal of Gerontological Social Work (JGSW). JGSW publishes scholarly articles devoted to social work practice, theory, administration, and consultation in the field of aging.

Gerontology Social Work Education Initiatives at UC Berkeley. Berkeley's School of Social Welfare offers a specialization in gerontology that prepares social work students to assume leadership roles in the delivery of services to older adults and their families. The Gerontology concentration, now more than 40 years old, includes both academic courses and supervised internship opportunities leading to a Master's degree in Social Welfare with a Concentration in Aging Services. Specialized gerontology courses provide students with state-of-the-art knowledge in the aging process, health and mental health issues, the aging service delivery network, and social policies that affect the elderly and their families, as well as a wide range of direct interventions with and on behalf of older adults and their families. Students also develop advanced practice skills through two years of internships in social service agencies serving older adults.

The School offers financial support to promising MSW and PhD students through targeted fellowships, including the Kleiner Doctoral Fellowship in Aging. The Kleiner Fellowship supports an individually-tailored program of research experience and training, including opportunities to participate in collaborative research activities through Berkeley's Center for the Advanced Study of Aging Services (CASAS). CASAS brings together School of Social Welfare faculty and graduate students, as well as academics from other departments, to address emerging issues in aging services.

\section{CONCLUSION}

Social workers have a unique combination of knowledge and skills that can improve the lives of older adults and their families and foster more agingfriendly communities. With adequate gerontological training, social workers can: (1) enhance the developmental, problem solving, and coping capacities of older people and their families; (2) promote the effective and humane operation of systems that provide resources and services to older people and their families; (3) link older people with systems that provide them with resources, services and opportunities; and, (4) contribute to the development and improvement of social policies that support persons throughout the lifespan (CaISWEC, 2006). These efforts are rooted in social work's basic commitment to individual auton- 
omy, person-centered care, family support, equitable service access, interdisciplinary collaboration, crosssystem coordination, and the well-being of vulnerable individuals, families, and communities.

As noted in a 2012 report by the National Association of Deans and Directors of Schools of Social Work, "Although not every student in a social work program will want to specialize in gerontology, every student should have an understanding of the ways in which aging issues impact older individuals, their families, neighborhoods, communities and organizations" (Bronstein et al., 2012, p. 5).
Ultimately, the goal of social work in aging is not simply the well-being of older adults, but the well-being of all individuals and communities - a society for all ages. As former UN Secretary General Kofi Annan said in introducing the United Nations Year of Older Persons on October, 1998: "A society for all ages is multigenerational. It is not fragmented, with youths, adults and older persons going their separate ways. Rather, it is age-inclusive, with different generations recognizing - and acting upon - their commonality of interest." The social work profession has a unique role to play in helping to achieve this vision.

\section{REFERENCES}

American Association of Retired Persons Public Policy Institute (AARP PPI). (2009). Beyond 50.09 chronic care: A call to action for health reform. Downloaded from http://assets.aarp.org/rgcenter/health/beyond_50_hcr.pdf

American Health Care Association (2013). Trends in nursing facility characteristics [on line] [Date of consulting: September 30, 2013]. Available from http://www. ahcancal.org/research_data/trends_ statistics/Documents/Trend_PVNF_FINALRPT_September2013.pdf

Applebum, R. (2012). Channeling: What we learned, what we didn't, and what it all means twenty-five years later. Generations, 36, 1, pp. 21-27.

Austin, C. D., Des Camp, E., Flux, D., McClelland, R. W. and Sieppert, J. (2005). Community development with older adults in their neighborhoods: The elder friendly communities program. Families in Society: The Journal of Contemporary Social Services, 86, 3, pp. 401-409. http:// dx.doi.org/10.1606/1044-3894.3438

Bandura, A. (1982). Self-efficacy mechanism in human agency. American Psychologist, 37, 2, 122.

Barusch, A. S. (2013). Age-Friendly Cities: A Social Work Perspective. Journal of gerontological social work, 56, 6, pp. 465472. http://dx.doi.org/10.1080/016343 72.2013 .826563

Béland, F., Bergman, H., Lebel, P., Clarfield, A. M., Tousignant, P., Contandriopoulos, A. and Dallaire, L. (2006). A system of integrated care for older persons with disabilities in Canada: Results from a randomized controlled trial. The Journals of Gerontology: Series A: Biological Sciences and Medical Sciences, 61 A, 4, pp.
367-373. http://dx.doi.org/10.1093/ gerona/61.4.367

Bernabei, R., Gambassi, G., Lapane, K., Landi, F., Gatsonis, C., Dunlop, R. and Mor, V. (1998). Management of pain in elderly patients with cancer: Correction. JAMA: Journal of the American Medical Association, 281, 2, p. 136 [on line]. Available from http://search.proquest.com/docview/619382631?accou ntid=14496

Boult, C., Rassen, J., Rassen, A., Moore, R. J. and Robison, S. (2000). The effect of case management on the costs of health care for enrollees in Medicare Plus Choice plans: A randomized trial. Journal of the American Geriatrics Society, 48, pp. 996-1001. http://dx.doi. org/10.1111/j.1532-5415.2009.02571.x

Boult, C., Green, A. F., Boult, L. B., Pacala, J. T., Snyder, C. and Leff, B. (2009). Successful models of comprehensive care for older adults with chronic conditions: evidence for the Institute of Medicine's "retooling for an aging America report. Journal of the American Geriatrics Society, 57, 12, pp. 2328-2337.

Bronstein, L.R., Brehl, P., Kropf, N., Volland, P., Barker, E. and Weiss, L. (2012). Educational, research and service enhancements in aging. Monograph commissioned by the NADD Gerontology task force and the John A. Hartford Foundation. Downloaded from http://www. naddssw.org/pages/wp-content/uploads/2013/12/Educational-researchservice-enhancements-in-aging-.pdf

Brown, R. (2009). The Promise of Care Coordination: Models that Decrease Hospitalizations and Improve Outcomes for Medicare Beneficiaries with Chronic IIInesses. A Report Commissioned by
The National Coalition on Care Coordination [on line]. Available from http:// www.nyam.org/social-work-leadershipinstitute/docs/N3C-Promise-of-CareCoordination.pdf

Burau, V., Theobald, $\mathrm{H}$. and Blank, R. H. (2007). Governing Home Care: A CrossNational Comparison. Northampton, MA: Edward Elger Publishing, Inc. http:// dx.doi.org/10.4337/9781847206862

California Social Work Education Center (CalSWEC) (2006). Aging competencies [on line]. Available from: http://calswec. berkeley.edu/files/uploads/pdf/CalSWEC/ AgingCompetencies_All_Feb2006.pdf

CBO. (2012). Lessons from Medicare's demonstration projects on disease management, care coordination, and value-based payment. Issue Brief. Downloaded from http://www.cbo. gov/sites/default/files/01-18-12-MedicareDemoBrief.pdf

Challis D. J., Chesterman R., Luckett R., Stewart K. J. and Chessum R. (2002). Care management in social and primary health care: The Gateshead Community Care Scheme. Hampshire, UK: Ashgate.

Challis, D., Hughes, J., Berzins, K., Reilly, S., Abell, J., Stewart, K. and Bowns, I. (2011). Implementation of case management in long-term conditions in England: Survey and case studies. Journal of Health Services Research \& Policy, 16, 1, pp. 8-13. http://dx.doi.org/10.1258/jhsrp. 2010.010078

Congressional Budget Office (CBO). (2012). Lessons from Medicare's Demonstration Projects on Disease Management, Care Coordination, and Value-Based Payment [on line]. [Date of consulting: January 5, 2013]. Available from http:// 
www.cbo.gov/sites/default/files/cbofiles/attachments/01-18-12-MedicareDemoBrief.pdf

Corrigan, P. W. (2006). Impact of consumeroperated services on empowerment and recovery of people with psychiatric disabilities. Psychiatric Services, 57, pp. 1493-1496. http://dx.doi.org/10.1176/ appi.ps.57.10.1493 / http://dx.doi. org/10.1176/ps.2006.57.10.1493

Counsell, S. R., Callahan, C. M., Clark, D. O., Tu, W., Buttar, A. B., Stump, T. E. and Ricketts, G. D. (2007). Geriatric care management for low-income seniors: A randomized controlled trial. JAMA: Journal of the American Medical Association, 298, 22, pp. 2623-2633. http:// dx.doi.org/10.1001/jama.298.22.2623

Cummings, S. M., Galambos, C., DeCoster, V. A. (2003). Predictors of MSW employment in gerontological practice. Educational Gerontology, 29, pp. 295-312. http://dx.doi.org/10.1080/713844338

Cummings, S. M., Alder, G., DeCoster, V. A. (2005). Factors influencing graduate social work students' interest in working with elders. Educational Gerontology, 31, pp. 643-655. http://dx.doi. org/10.1080/03601270591003382

Damron-Rodriguez, J. (2005). Reality check: Social work. White House Conference on Aging Mini-Conference on Geriatric Healthcare Workforce Issues, July 16, 2005, Bethesda, MD.

Damron-Rodriguez, J. A. (2006). Moving ahead: Developing geriatric social work competencies. Handbook of social work in health and aging, pp. 1051-1068.

Dobriansky, P. J., Suzman, R. M. and Hodes, R. J. (2007). Why population aging matters: A global perspective. National Institute on Aging, National Institutes of Health, US Department of Health and Human Services, US Department of State.

Enguidanos, S. M. and Jamison, P. M. (2006). Moving from tacit knowledge to evidence-based practice: the Kaiser Permanente community partners study. Home health care services quarterly, 25, 1-2, pp. 13-31.

Enguidanos, S., Hoang, T., Hillary, K. A. and Haynes, R. L. (2011). Predictors of hospitalization among Home Health Managed Care patients. Home Health Care Management \& Practice, 23, 5, pp. 363-372. http://dx.doi. org/10.1177/1084822310388138
Federal Interagency Forum on Aging-Related Statistics. (2008). Older Americans 2008: Key indicators of well-being. Washington, DC: U.S. Government Printing Office.

Feldman, P. H., Oberlink, M. R., Simantov, E. and Gursen, M. D. (2004). A tale of two older Americas: Community opportunities and challenges. Advantage Initiative 2003 National Survey of Adults Aged 65 and Older. New York, NY: Center for Home Care Policy and Research, Visiting Nurse Service of New York.

Freij, M., Weiss, L., Gass, J., Trezza, C., Wiener, A., Melly, J., Volland, P. (2011). «Just like I'm saving money in the bank»: Client perspectives on care coordination services. Journal of Gerontological Social Work, 54, 7. http://dx.doi.org/10.1 080/01634372.2011.594490

Frey, W. H. (2007). Mapping the Growth of Older America: Seniors and Boomers in the Early 21st Century. Brookings Census 2000 Series. Washington, D.C.: Brookings Institution Metropolitan Policy Program.

G8 Information Centre. (2000). G8 Turin Charter: Towards active ageing [on line]. [Date of consulting: September 30, 2013]. Available from: http:// www.g8.utoronto.ca/employment/labour2000_ageing.htm

Hodge, G. (2008). The geography of aging: Preparing communities for the surge in seniors. Montreal: McGill-Queen's University Press.

Hooyman, N. R. (2006). Achieving curricular and organizational change: Impact of the CSWE geriatric enrichment in social work education project. Council on Social Work Education.

Houser, A. and Gibson, M. J. (2008). Valuing the invaluable: The economic value of family caregiving, 2008 update [on line]. Available from http://assets.aarp. org/rgcenter/il/i13_caregiving.pdf

Houser, A., Fox-Gage, W. and Gibson, M. J. (2009). Across the states in 2009: Profiles of long-term care and independent living [on line]. Available from http://assets.aarp.org/rgcenter/il/ d19105_2008_ats.pdf

Hudson, R. B. (2002). Workers of color and pathways to retirement. In Hudson, R. B. (ed.). Public Policy and Aging Report, Spring 2002. Washington, DC: Gerontological Society of America.
Hyduk, C. A. (2002). Community-based long-term care case management models for older adults. Journal of Gerontological Social Work, 37, 1, pp. 19-47. http://dx.doi.org/10.1300/ J083v37n01_03

Ikegami, N. and Campbell, J. C. (2002). Choices, policy logics and problems in the design of long-term care systems. Social Policy \& Administration, 36, 7, pp. 719-734. http://dx.doi. org/10.1111/1467-9515.t01-1-00313

Itzhaky, H. and York, A. S. (2000a). Empowerment and community participation: Does gender make a difference? Social Work Research, 24, 4, pp. 225-234. http://dx.doi.org/10.1093/ swr/24.4.225

Itzhaky, H. and York, A. S. (2000b). Sociopolitical control and empowerment: An extended replication. Journal of Community Psychology, 28, 4, pp. 407415. http://dx.doi.org/10.1002/1520$6629(200007) 28: 4<407:$ :AID JCOP3>3.0.CO;2-R / http:// dx.doi.org/10.1002/1520$6629(200007) 28: 4<407:$ :AlD JCOP3>3.3.CO;2-I

Kaiser Family Foundation. (2010). Health Care Reform and the CLASS Act. Washington, DC: Kaiser Family Foundation. Available from http://www.kff.org/ healthreform/upload/8069.pdf

Kane, R. A. (2012). Thirty years of homeand community-based services: Getting closer and closer to home. Generations, 36, 1, pp. 6-13.

Kelsey, S. G. and Laditka, S. B. (2009). Evaluating the roles of professional geriatric care managers in maintaining the quality of life in older americans. Journal of Gerontological Social Work, 52, 3, pp. 261-276. http://dx.doi. org/10.1080/01634370802609171

Knickman, J. R. and Snell, E. K. (2002). The 2030 problem: Caring for aging baby boomers. Health Services Research, 37, pp. 849-884. http://dx.doi. org/10.1034/j.1600-0560.2002.56.x

Knickman, J. and Snell, E. (2008). The 2030 problem: Caring for aging baby boomers". In Harrington, C., Estes, C. and Crawford, C. (eds.). Health policy: Crisis and reform in the U.S. health delivery system (4th ed.). Sudbury, MA: Jones \& Bartlett, pp. 114-122.

Komisar, H. and Thompson, L. S. (2007). National spending for long-term care. 
Washington DC: Georgetown University Long-Term Care Financing Project. Available from http://ltc.georgetown. edu/pdfs/natspendfeb07.pdf

Leading Age. (2013). About Leading Age [on line]. [Date of consulting: September 30, 2013]. Available from http://www. leadingage.org/About_LeadingAge.aspx

Lehning, A. J., Scharlach, A. E. and Wolf, J. P. (2012). An emerging typology of community aging initiatives. Journal of Community Practice, 20, pp. 293-316. http://dx.doi.org/10.1080/10705422.2 012.700175

Mason, S. E. and Sanders, G. R. (2004). Social work student attitudes on working with older clients. Journal of Gerontological Social Work, 42, pp. 61-75. http://dx.doi.org/10.1300/ J083v42n03_05

McDonough, K. E. and Davitt, J. K. (2011). It takes a village: Community practice, social work, and aging-in-place. Journal of Gerontological Social Work, 5, 5, pp. 528-541. http://dx.doi.org/10.1080/01 634372.2011.581744

Montgomery, R. J. V. (1999). The family role in the context of long-term care. Journal of Aging and Health, 11, 3, pp. 401-434. http://dx.doi. org/10.1177/089826439901100307

Moon, A., Wilson, S., Takahashi, N., DamronRodriguez, J. and Goodman, C. (2008). CaISWEC Aging Initiative labor force survey I: Public services for older adults [on line]. Available from: http://calswec. berkeley.edu/CalSWEC/indexAge.html

National Association for Home Care and Hospice. (2008). Basic statistics about home care. Washington, DC: $\mathrm{NAHCH}$ [on line]. [Date of consulting: December 31, 2009]. Available from: http://www. nahc.org

National Association of Social Workers (NASW). (2005). Assuring the sufficiency of a frontline workforce: A national study of licensed social workers. Special report: Social work services for older adults. Washington, DC: NASW.

Onder, G., Finne-Soveri, H., Soldato, M., Liperoti, R., Lattanzio, F., Bernabei, R. and Landi, F. (2009). Distress of caregivers of older adults receiving home care in european countries: Results from the AgeD in HOme care study. The American Journal of Geriatric Psychiatry, 7, 10, pp. 899-906. http://dx.doi.org/10.1097/ JGP.0b013e3181b4beef
Parker, L. and Betz, D. (1996). Diverse partners in planning and decision making, Community ventures. Circular Series, WSU Cooperative Extension Bulletin. Pullman, WA: Washington State University.

Passel, J. S. and Cohn, D’V. (2008). US population projections, 2005-2050. Pew Research Center.

Peak, T., Toseland, R. W. and Banks, S. M. (1995). The impact of a spouse-caregiver support group on care recipient health care costs. Journal of Aging and Health, 7, 3, pp. 427-449. http://dx.doi. org/10.1177/089826439500700306

Price, R. H. and Behrens, T. (2003). Working Pasteur's quadrant: Harnessing science and action for community change. American Journal of Community Psychology, 31, 3-4, pp. 219-223. http:// dx.doi.org/10.1023/A:1023950402338

Rizzo, V. M. and Rowe, J. M. (2006). Studies of the cost-effectiveness of social work services in aging: A review of the literature. Research on Social Work Practice, 16, 1, pp. 67-73. http://dx.doi. org/10.1177/1049731505276080

Sampson, R. J. and Raudenbush, S. W. (1999). Systematic social observation of public spaces: A new look at disorder in urban neighborhoods. American Journal of Sociology, 105, pp. 603-651. http://dx.doi.org/10.1086/210356

Scharlach, A. (1999). Special topics in human development: The aging process. In Richardson, V. (ed.). Teaching gerontological social work: A compendium of model syllabi. Alexandria, VA: Council on Social Work Education.

Scharlach, A. (2009). Frameworks for fostering aging-friendly community change. Generations, 33, 2, pp. 71-73.

Scharlach, A., Damron-Rodriguez, J. A., Robinson, B. and Feldman, R. (2000). Educating social workers for an aging society: A vision for the twenty-first century. Journal of Social Work Education, 36, pp. 521-538.

Scharlach, A. (2002). Direct practice in aging settings. In Kropf, $\mathrm{N}$. and Tompkins, C. (eds.). Teaching aging. Alexandria, VA: Council on Social Work Education.

Scharlach, A., Giunta, N., Chow, J. and Lehning, A. (2008). Racial and ethnic variations in caregiver service use. Journal of Aging and Health, 20, pp. 320-346. http://dx.doi. org/10.1177/0898264308315426
Scharlach, A., Giunta, N., Robinson, B. and Dal Santo, T. (2003). Care management in long-term care insurance; Meeting the needs of policyholders? Care Management Journal, 4, 2, pp. 73-81.

Scharlach, A., Graham, C. and Lehning, A. (2012). The "village" model: A consumer-driven approach for aging in place. The Gerontologist, 52, 3, pp. 418-427. http://dx.doi.org/10.1093/geront/ gnr083

Scharlach, A., Graham, C. and Berridge, C. (2012). ElderHelp Concierge Club evaluation. Unpublished report available from the University of California at Berkeley, Center for the Advanced Study of Aging Services.

Scharlach, A., Kellam, R., Ong, N., Baskin, A., Goldstein, C. and Fox, P. (2006). Cultural attitudes and caregiver service use: Lessons from focus groups with racially and ethnically diverse family caregivers. Journal of Gerontological Social Work, 47, 1-2, pp. 133-156. http:// dx.doi.org/10.1300/J083v47n01_09

Scharlach, A. and Lehning, A. (2012). Government's role in aging and long-term care. In J. Hacker, J. O'Leary, A. (eds.). Shared risks, shared responsibilities: Government, markets and social policy in the twenty-first century. New York: Oxford University Press.

Scharlach, A. and Robinson, B. (2005). The Consortium for Social Work Training in Aging: Scools of social work in partnership with country departments of adult and aging services. Journal of Social Work Education, 41, 3, pp. 427-440. http://dx.doi.org/10.5175/ JSWE.2005.200400410

Scharlach, A., Simon, J. and Dal Santo, T. (2002). Who is providing social services today older adults: Implications of a survey of aging services personnel. Journal of Gerontological Social Work, 38, 4, pp. 5-17. http://dx.doi.org/10.1300/ J083v38n04_03

Seperson, S. B. (2002). Demographics about aging. In Seperson, S. B. and Hegeman, C. R. (eds.), Elder care and service learning: A handbook. Westport, CT: Auburn House, pp. 17-30.

Shea, D., Davey, A., Femia, E. E., Zarit, S. H., Sundström, G., Berg, S. and Smyer, M. A. (2003). Exploring assistance in Sweden and the United States. The Gerontologist, 43, 5, pp. 712-721. http://dx.doi. org/10.1093/geront/43.5.712 
Shier, G., Ginsburg, M., Howell, J., Volland, P. and Golden, R. (2013). Strong social support services, such as transportation and help for caregivers, can lead to lower health care use and costs. Health Affairs, 32, 3, pp. 544-551. http://dx.doi.org/10.1377/ hlthaff.2012.0170

Shirk, C. (2006). Rebalancing long-term care: The role of the Medicaid HCBS Waiver Program. National Health Policy Forum. Available from: http://www. nhpf.org/library/background-papers/ BP_HCBS.Waivers_03-03-06.pdf

Soldo, B. J., Mitchell, O. S., Tfaily, R. and McCabe, J. F. (2006). Cross-cohort differences in health on the verge of retirement. National Bureau of Economic Research Working Paper No. 12762. Downloaded from http://www.nber. org/papers/w12762

Tourigny, A., Durand, P. J., Bonin, L., Hébert, R. and Rochette, L. (2004). Quasi-experimental study of the effectiveness of an integrated service delivery network for the frail elderly. Canadian Journal on Aging, 23, 3, pp. 231-246. http://dx.doi. org/10.1353/cja.2004.0038

United Nations, Department of Economic and Social Affairs, Population Division. (2005). World population prospects. The 2004 revision. New York: United Nations.

U. S. Administration on Aging. (2012). Older Americans Act and the aging network. Downloaded from http://www.aoa. gov/AoA_programs/OAA/

U. S. Census Bureau (2010). The next four decades: The older population in the United States: 2010 to 2050. U.S. Department of Commerce, Economics and Statistics Administration, No. 1138. Downloaded from http://www.census. gov/prod/2010pubs/p25-1138.pdf

U.S. Department of Health and Human Services (1998). Informal caregiving: Compassion in action. Washington, DC: U.S. Department of Health and Human Services [on line]. [Date of consulting July
20, 2009]. Available from: http://aspe. hhs.gov/daltcp/Reports/carebro2.pdf

U.S. Department of Health and Human Services. (2006). The supply and demand of professional social workers providing long-term care services: Report to Congress. Washington, DC: Department of Health and Human Services.

Vincent, G. and Velkoff, V. (2010). The next four decades: The older population in the United States 2010 to 2050. Washington, DC: US Government Printing Office.

Whitfield, K. E. and Hayward, M. (2003). The landscape of health disparities among older adults. Public Policy \& Aging Report, 13, 3, pp. 1-7. http://dx.doi. org/10.1093/ppar/13.3.1

Zimmerman, M. A. and Rappaport, J. (1988). Citizen participation, perceived control, and psychological empowerment. American Journal of Community Psychology, 16, pp. 725-750. http:// dx.doi.org/10.1007/BF00930023 